\title{
ОСОБЛИВОСТІ ЗБИРАННЯ ДОКАЗІВ ЯК СТРУКТУРНОГО ЕЛЕМЕНТА ДОКАЗУВАННЯ ОБСТАВИН, ПЕРЕДБАЧЕНИХ СТ.96-3 КРИМІНАЛЬНОГО КОДЕКСУ УКРАЇНИ
}

\section{ПАНЬКО Мар'яна Свгенівна - аспірант кафедри кримінального права та процесу Львівського торговельно-економічного університету}

Здійснено аналіз регламентачї заходів кримінально-правового характеру щодо юридичних осіб узаконодавстві Украӥни, досліджено погляди науковиів щодо доцільності запровадження таких заходів. Вивчається проблема природи таких заходів. Акцентується увага на тому, що заходи щодо юридичних осіб є особливим видом юридичної відповідальності. у статті також вивчаються особливості збирання доказів як структурного елементу доказування для застосування щодо юридичних осіб заходів кримінально-правового характеpу. Розглянуто концептуальні проблеми доказування за чинним КПК України та зроблено відповідні узагальнення, спрямовані на вдосконалення його засобів у кримінальному провадженні. На підставі аналізу чинного законодавства, наукових джерел відповідної спрямованості здійснено дослідження нормативного змісту збирання доказів та борм його реалізації. Проведено аналіз витребування речей чи документів, тимчасового доступу до речей чи документів та обшуку. Проаналізована практика застосування відповідних норм кримінального прочесуального законодавства Украӥни. Встановлено, шзо збирання доказів це складання певних доказових фактів у єдине иіле, отримання різноманітної доказової інбормачї з різних джерел та від різних осіб, а також відбір такої інббормачї. За результатами дослідження приписів чинного законодавства, наукових позицій теоретиків права та судової практики виділяються окремі дискусійні аспекти та проблемні моменти у контексті застосування заходів кримінальноправового характеру.

Ключові слова: доказування, збирання доказів, юридична особа, заходи кримінальноправового характеру, слідчі (розшукові) дї, негласні слідиі (розшукові) дї.

\section{Постановка проблеми}

На підставі Закону України від 23 червня 2013 року № 314-VII «Про внесення змін до деяких законодавчих актів України щодо виконання Плану дій щодо лібералізації Европейським Союзом візового режиму для України стосовно відповідальності юридичних осіб», до КПК України (п.7 ч.1 ст. 91) та Загальної частини КК України (статті 96-1 - 96-10 Розділу XIV-1) були внесені зміни, в частині введення інституту заходів кримінально-правового характеру щодо юридичних осіб. Відповідні нововведення опинилися під пильним науковим прицілом та отримали як підтримку, так i гостру критику.

Прихильники впровадження інституту заходів кримінально-правового характеру щодо юридичних осіб як аргумент наводять те, що їх складна організаційна структура, значна кількість осіб, залучених у сферу цієї діяльності, а також певна децентралізація управління сприяє збільшенню кількості фактів учинення протиправних дій 3 їх боку, що зумовило потребу у запровадженні прямих каральних санкцій безпосередньо до юридичних осіб з метою посилити контроль за негативними наслід- 
ками господарської діяльності. Окрім того, розмір збитків, які завдаються злочинною діяльністю підприємств, установ чи організацій не можливо переоцінити, оскільки вони, у більшості випадків, носять катастрофічний характер [1, с.124].

Натомість, критики вказують на те, що ідея посилення відповідальності юридичних осіб за вчинені правопорушення повинна втілюватись у межах цивільного, податкового, фінансового, трудового та інших (відмінних від кримінального) галузей права із застосуванням до юридичних осіб санкцій майнового та організаційного характеру. Існуюча ж модель заходів кримінально-правового характеру не може претендувати на ефективність, оскільки санкції переважно фінансового характеру будуть просто перекладатись на «плечі» працівників та їх родин, меншою мірою на ділових партнерів і споживачів (шляхом підвищення вартості товарів і послуг через застосовані санкції) i, таким чином, реальний фінансовий тягар покладатиметься не на юридичні особи [2, с.105, 113].

Однак, не вступаючи у полеміку «рro» чи «contra», слід зазначити, що узагальнення практики правозастосовних органів свідчить про те, що вони стикаються 3 певними труднощами щодо доказування обставин, які є підставою для застосування щодо юридичних осіб заходів кримінальноправового характеру. Очевидно, що такий стан речей зумовлений недоліками в конструюванні кримінально-правових та кримінально-процесуальних норм, та, власне, полярністю позицій науковців. Окрім того, даний інститут є ще відносно новим, дієве застосування якого можливе лише з часом та потребує удосконалення положень закону 3 урахуванням практики його застосування, а також сумлінності самого правозастосувача, його правової культури та незаангажованості.

\section{Аналіз останніх досліджень}

Поняття збирання доказів у кримінальному провадженні розглядалися у працях Н.Р. Бобечка, В.К.Волошиної, М.О. Гетманцева, І.Ю. Кайла, В. Г. Аукашевич, Р.В.Малюги, Т.М. Мирош- ниченка, О. С. Осетрової, М.А. Погорецького, Д.Б. Сергеєвої, С.М. Сівочка, А.Т.Ульянової, А.В. Шевчишина та інших. Водночас, питання збирання доказів як структурного елементу доказування обставин, які є підставою для застосування щодо юридичних осіб заходів кримінально-правового характеру не розглядалися жодним науковцем. Такий стан речей власне зумовлений тим, що інститут заходів кримінально-правового характеру є ще відносно новим, дієве застосування якого можливе лише з часом та потребує удосконалення положень закону з урахуванням практики його застосування, а також сумлінності самого правозастосувача, його правової культури та незаангажованості.

\section{Постановка завдання}

Метою даної статті є дослідження особливостей збирання доказів як структурного елементу доказування обставин, які 6 підставою для застосування щодо юридичних осіб заходів кримінально-правового характеру.

\section{Виклад основного матеріалу}

Доказування 6 фундаментальною науковою і правовою категорією кримінального процесу, яка визначає його основний зміст, функціонування усіх його інститутів та впливає на організацію і діяльність правозастосовних органів, які здійснюють кримінальне провадження, а також усіх інституцій, які забезпечують здійснення цього провадження. Воно полягає у складному та багатогранному відображенні правозастосовної діяльності, яка спрямована на встановлення об'єктивної істини у справі та являє собою поєднання практичних дій і мислення, фізичної і розумової діяльності учасників кримінального провадження [3, c.117]. Доказування є ефективним процесуальним засобом встановлення істини та прийняття об'єктивно мотивованих рішень у кримінальному провадженні. Воно має юридично значущий зміст та об'єктивно виражену зовнішню форму, яка залежить від сукупності елементів, сторін, властивостей і зв'язків процесу доказування. 


\section{Дискусії, обговорення, актуально}

У КПК України чітко визначені структурні елементи доказування (ч. 2 ст. 91), якими $є$ збирання, перевірка та оцінка доказів $з$ метою встановлення обставин, що мають значення для кримінального провадження. У теорії кримінального процесуального права не існує єдності думок щодо змісту поняття «збирання доказів», доцільності його застосування та форм. 3 цього приводу можна виділити, принаймні, три позиції. Так, представники першої

трактують поняття «збирання доказів» як виявлення, фіксацію та їх дослідження [4, с.61; 5, с. 33]. В цьому випадку навряд чи правильно розглядати поняття «дослідження» як форму збирання доказів, оскільки така діяльність притаманна для здійснення перевірки доказів. Окрім того, науковцями «упущено» поняття фіксації доказів, оскільки фактичні дані повинні бути належним чином закріплені за допомогою процесуальних засобів, тобто мати певну законодавчо регламентовану форму, що дозволить їх подальше використання для прийняття процесуальних рішень.

В свою чергу, представники другої позиції взагалі пропонують відмовитись від використання терміну «збирання доказів», замінивши його на юридичну конструкцію «отримання доказів». Свою позицію мотивують тим, що збирання фактичних даних ще не означає можливість іiї використання у кримінальному провадженні, адже не виключені випадки, коли затрачені зусилля на здобуття доказової інформації $\epsilon$ марними, оскільки така інформація не вказує на можливість ії використання як доказу у кримінальному провадженні. Окрім того вказується, що розуміння під початковим етапом доказування «збирання доказів» на практиці призводить до того, що окремі працівники правоохоронних органів помилково вважають, що отримані ними в ході оперативно-розшукового документування певні об'єкти речового походження чи документи, а інколи й вербальна інформація вже є доказом у кримінальному провадженні[6, с. 67].

Слід зазначити, що у тлумачному словнику української мови поняття «отримувати» є недоконаним видом дієслова, що означає брати, приймати те, що надсилається, надається, вручається і т. ін.; здобувати, діставати що-небудь певними зусиллями, якимись діями і т. ін.[7, с.625]. Тобто значення слова «отримати» зводиться до можливості здобуття доказової інформації за допомогою певних зусиль чи дій, що зовсім не відображає істинного призначення такої дії у процесі доказування. Окрім того, видається, що «отримання доказів» $є$ більш вужчим поняттям, ніж «збирання доказів». Це також випливає з аналізу КПК України, де отримання речей, документів, відомостей (ст.93) є лише частиною процесу збирання доказів.

Нарешті, представники третьої позиції доводять доцільність застосування поняття «формування доказів» [8, с. 212],яке тлумачиться якнадання чому-небудь певної форми, завершеності, визначеності, складання цілого 3 частин, виникнення,створення, породження чого-небудь [9, с.283]. Однак із цією позицією теж не можна погодитись, оскільки формування доказів, скоріш за все, охоплює весь процес збирання, перевірки фактичних даних до моменту визнання їх доказами у кримінальному провадженні. Як бачимо кожна із заведених позицій має принципові розбіжності щодо використання самого поняття «збирання доказів» та окремих його форм. Водночас, видається, що законодавець цілком виправдано до одного із структурних елементів доказування відносить збирання доказів. Поняття «збирати» означає складати що-небудь докупи, в одне місце; поступово приєднувати, складати що-небудь одне до одного, частину до частини; нагромаджувати; брати що-небудь з різних місць, від різних осіб і т. ін.; відбирати потрібні предмети 3-поміж інших[10, c. 434]. Тобто збирання доказів відображає ті дії, які спрямовані на досягнення результату доказування, а саме - складання певних доказових фактів у єдине ціле, отримання різноманітної доказової інформації з різних джерел та від різних осіб, а також відбір такої інформації.

Першочерговою формою збирання доказів $\epsilon$ їх виявлення, яке полягає в їх пошуку, у зверненні уваги на ті чи інші сліди, обставини, фактичні дані, які можуть мати 
значення для кримінального провадження. Виявлення доказів, як правило, відбувається під час проведення слідчих (розшукових) та негласних слідчих (розшукових) дій [9, с.281]. Так, під час доказування обставин, які є підставою для застосування щодо юридичних осіб заходів кримінально-правового характеру, в першу чергу, необхідно зібрати докази, які вказують на вчинення одного з кримінальних правопорушень, перелік яких передбачений ст.96-3 КК України. На первинному етапі збирання доказів органу досудового розслідування достовірно не відомо якою буде кінцева кваліфікація суспільно-небезпечного діяння суб'єкта кримінального правопорушення, а відповідно складно встановити чи є можливість для застосування щодо юридичних осіб заходів кримінально-правового характеру.

Так, наприклад, якщо особа вчинила кримінальне правопорушення проти основ національної безпеки України (ст.113), виявленню підлягають факти, які підтверджують, що в його діяннях мало місце посягання на внутрішню (економічну, екологічну, воєнну тощо) безпеку України. При розслідуванні цього кримінального правопорушення, необхідно провести огляд місця події з метою виявлення осередку вибуху, підпалу тощо, знарядь та засобів, які використовувались для вчинення злочину. Необхідно також встановити наявність на місці події камер відеоспостереження на спорудах та будівлях, осіб, яким відомі обставини вчинення диверсії, координати базових станцій операторів мобільного зв'язку (для встановлення абонентів мобільного зв'язку, які знаходились на місці подіiі). Окрім того, слід здійснити тимчасовий доступ до інформації, яка перебуває в операторів мобільного зв'язку про вхідні та вихідні з'єднання у період вчинення кримінального правопорушення на місці події. В подальшому необхідно встановити осіб, які здійснювали телефонні дзвінки, визначити між ними групи абонентів, які були взаємопов'язані між собою та перевірити їх причетність до вчинення кримінального правопорушення.

Тобто на цьому етапі робота органу досудового розслідування спрямована на ви- явлення доказів, які підтверджують факт вчинення кримінального правопорушення конкретними особами. Таким чином доказування обставин, які є підставою для застосування щодо юридичних осіб заходів кримінально-правового характеру є можливим лише після встановлення осіб, причетних до вчинення кримінального правопорушення, оскільки в такому випадку можна прослідкувати зв'язок між суб'єктом та юридичною особою від імені чи в інтересах якої було вчинено кримінальне правопорушення. Такий зв'язок виявляється у ході проведення слідчих (розшукових) та негласних слідчих (розшукових) дій, вжиття заходів забезпечення кримінального провадження. Зокрема, у ході допиту службових осіб юридичної особи можна з'ясувати, яке відношення підозрюваний має до юридичної особи, чи $\mathrm{\epsilon}$ він іiі уповноваженою особою тощо. Під час обшуку за місцем проживання підозрюваного можна здобути докази його злочинної діяльності, здійснюваної від імені та в інтересах юридичної особи (наприклад, квитанції про переказ коштів, печатки, офіційні бланки, статутні документи, друкарські верстати тощо). У ході зняття інформації з транспортних телекомунікаційних мереж, аудіо-, відеоконтролю особи, спостереження за особою, моніторингу банківських рахунків (у випадку підслідності детективів НАБУ) можна здобути докази приховування слідів вчинення кримінального правопорушення від імені чи в інтересах юридичної особи.

Другою формою збирання доказів у кримінальних провадженнях 6 їх фіксація. Процесуальне закріплення виявлених i одержаних фактичних даних є абсолютно необхідним актом будь-якої процесуальної дії із збирання доказів, без якого з пізнаних фактичних даних неможливо сформувати доказ. Тому отримана суб'єктом доказування доказова інформація у вигляді матеріальних або ідеальних відображень може бути використана в процесуальному доказуванні лише після надання їй встановленої законом форми [11, с.25]. Отже доказ має містити не лише якісну компоненту бути наповненим певним юридичним змістом, а й мати зовнішне вираження - певну 


\section{Дискусіі, обговорення, актуально}

законодавчо регламентовану форму, що дозволить його подальше використання для прийняття процесуальних рішень.

Процесуальні дії під час кримінального провадження можуть фіксуватися у протоколі; на носії інформації, на якому за допомогою технічних засобів зафіксовані процесуальні дії; у журналі судового засідання (ст. 103 КПК України). Фіксація обставин, які 6 підставою для застосування щодо юридичних осіб заходів кримінально-правового характеру здійснюється одночасно 3 фіксацією факту вчинення кримінального правопорушення. Так, у кримінальних провадженнях про корупційні злочини (ч.1,2 ст. 368-3, ч.1, 2 ст. 368-4, ст. 369 i 369-2 КК України) орган досудового розслідування, проводячи комплекс слідчих (розшукових) та негласних слідчих (розшукових) дій, здійснюе фіксацію факту надання (одержання) неправомірної вигоди та водночас фіксує підстави для застосування заходів кримінально-правового характеру щодо юридичних осіб. Зокрема, під час проведення аудіо-, відеоконтролю особи, зняття інформації 3 транспортних телекомунікаційних мереж, контролю за вчиненням кримінального правопорушення, у протоколах та на носіях інформації можуть бути зафіксовані докази вчинення корупційного злочину від імені та в інтересах юридичної особи, а саме: у розмовах вигододавця та вигодоодержувача зафіксовано, що неправомірна вигода надавалася 3 метою прийняття службовою особою рішення на користь юридичної особи. Так, наприклад, уповноважена особа юридичної особи звернулася до судді з пропозицією надання останньому неправомірної вигоди $з$ метою задоволення своїх позовних вимог. В подальшому під час проведення контролю за вчиненням злочину та аудіо-, відеоконтролю особи, здійснюється фіксація факту передачі та вилучення предмета неправомірної вигоди. Таким чином фіксується одна iз умов застосування щодо юридичних осіб заходів кримінально-правового характеру (вчинення одного з кримінальних правопорушень, перелік яких передбачений ст.963 КК України).

\section{Висновки}

Таким чином збирання (виявлення та фіксація) доказів для встановлення обставин, які є підставою для застосування щодо юридичних осіб заходів кримінально-правового характеру включає сукупність дій, які спрямовані на досягнення результату доказування, а саме - складання певних доказових фактів у єдине ціле, отримання різноманітної доказової інформації з різних джерел та від різних осіб, а також відбір такої інформації.

\section{Лiтература}

1. Сагайдак E.С. До питання про встановлення кримінальної відповідальності юридичних осіб в Україні / E.С. Сагайдак // Університетські кримінально-правові та кримінологічні читання. 3б. тез доп. I Bceукр. курсант.-студент. наук.-практ. конф. (16 черв. 2017 р., м. Харків) / МОН України; Кримінол. асоц. України. - Харків, 2017 - С.123-127

2. Дудоров О.О. Кримінальна відповідальність американських корпорацій за економічні злочини: від витоків до сьогодення / О.О. Дудоров, Д.В. Каменський // Право і громадянське суспільство. - №2 2015 р. - С.103-145

3. Мотлях О.I. Криміналістичне доказування у кримінальному провадженні: теоретико-процесуальний аспект / O.I. Мотлях, С.В. Вороніна // Науковий вісник Ужгородського національного університету. - 2012 р. - Вип. 20, ч.1, т. 4. - С.117-120

4. Михайловская И.Б. Настольная книга судьи по доказыванию в уголовном процессе/ И.Б. Михайловская - М.: ТК Велби, Изд-во Проспект, 2006. - 192 с.

5. Карнеева Л.M. Доказательства и доказывание в уголовном процессе. Учебное пособие / А.М.Карнеева. - М.: Юрид. лит. 1994. - 193 с.

6. Погорецький М.А. Нова концепція кримінального процесуального доказування / М.А. Погорецький // Вісник кримінального судочинства. - 2015 р. - №3 - С.63-79

7. Словник української мови: в 11 томах. - Том 5, 1974. - Стор. 625. // [Електронний ресурс]. - Режим доступу: http:// sum.in.ua/s/oderzhuvaty 
8. Шумило М. Є. Докази досудового і судового провадження в КПК України: співвідношення та їх функціональне призначення / М. Є.Шумило // Право України. - 2013. - № 11. - C. 206-215.

9. Малюга Р.В. Доказування в кримінальному процесі: проблеми визначення структурних елементів / Р.В. Малюга // // Наукові записки Аьвівського університету бізнесу та права. - 2013. - Вип. 11. - С. 280283. - Режим доступу: http://nbuv.gov.ua/ UIRN/Nzlubp $2013 \quad 1171$

10. Словник української мови: в 11 томах. - Том 3, 1972. - Стор. 434. // [Електронний ресурс]. - Режим доступу: http://sum. in.ua/s/zbyraty

11. Гончаренко В. Г. Доказування в кримінальному провадженні : науковопрактичний посібник / В.Г. Гончаренко; Академія адвокатури України. - К.: Прецедент, 2014. - 42 с.

SUMMARY
The work analyzes implementation of criminal
law measures against legal entities in the Ukrainian
legislation, as well as the condition of the legislation
pertaining to this issue. The problem concerning
nature of such measures have been studied. It has
been focused on the fact that the measures against
legal entities are special kind of legal liability
other then criminal liability.Articolul examineaza
particularitatile verificarii si collecting evidenceon
the application of criminal law for legal entities.
Also the article deals with the conceptual problems
of proof under the existing Code of Criminal
Procedure and the corresponding generalizations
made aimed at improving his means in criminal
proceedings.It is carried out the research of the
normative content collectingof evidence and the
forms of its realization based on the analysis of
current legislation, scientific sources according to
the direction.A comparative analysis of demanding
things or documents, temporary access to things or
documents and searching. Analyzed the practice of
the relevant rules of criminal procedure legislation
of Ukraine.It is established that the gathering of
evidence is the compilation of certain evidentiary
facts into a single whole, obtaining various
evidence from various sources and from different
persons, and also the selection of such information.
Based on the research results of current legislation,
scientific positions of theorists of law and legal
practice it highlights some controversial aspects
and problem areas, especially in the context of the
application of measures concerning criminal law.
Keywords: criminal procedural law,
collecting evidence, legal entity, criminal law
measures, investigation (searching) actions, secret
investigation (searching) actions.

